\title{
Strategies on C-E Translation of Xi'an Red Tourism Based on the Belt and Road Initiative
}

\author{
Chen $\mathrm{Ke}^{1}$ \\ College of Foreign Languages \\ Xi'an Shiyou University \\ Xi'an, China \\ kechen.112233@163.com
}

\author{
Zhang Mengya ${ }^{2}$ \\ College of Foreign Languages \\ Xi'an Shiyou University \\ Xi'an, China \\ 397646641@qq.com
}

\begin{abstract}
In order to spread the red culture, this paper explores strategies on C-E Translation of Xi'an red tourism, and tries to solve the problems which brought about by differences in social ideology, value idea, audience psychology, and cultural background. Under the premise of equal exchanges between Chinese culture and western culture, translation strategies such as "Adaptation strategy" "Overall strategy" "Cultural connection strategy" "Unification strategy" and "Rearrangement strategy" are used to ensure we are in the favorable place to seize the initiative in the international communication. Foreign exchange and cooperation based on $\mathrm{C}-\mathrm{E}$ translation will make the audience of the target language have a cognitive sense of the red culture, then form an identical sense of the red culture, so as to achieve the effect on C-E translation of the red tourism to its maximum. The process of red culture's external diffusion and transfer is actually a process of sharing part of our national development history with the outside world. It meets the requirement of the times as well as the contemporary challenge.
\end{abstract}

Keywords-C-E translation; red tourism; translation strategies; the Belt and Road initiative

\section{INTRODUCTION}

The implementation of the Belt and Road initiative has brought unprecedented opportunities to the tourism industry in Xi'an, the birthplace of ancient Chinese culture. Tourism, a pleasing enjoyment and a blend of diverse cultures, becomes a kind of life style in contemporary society. Apart from the cultural landscape and natural landscape, Xi'an is rich in tourism resources, attracting a large number of tourists from home and abroad, especially the hot red tourism in recent years has also become a symbol of this city. It not only contains certain natural landscapes but also specific historical culture [1] Red tourism is not only the combination of the red cultural landscape and green natural scenery, but also the integration of patriotic education and economic development; it reproduces our glorious revolutionary history as well as the important task of strengthening revolutionary history and traditional education, so that tourists will get spiritual sublimation and willpower enhancement while relaxing themselves. In terms of economy, red tourism based on historical spirits integrates an endless stream of new-age elements into a comprehensive and coordinated scientific and sustainable development; in terms of culture, red tourism not only allows foreign tourists to

This work was financially supported by the Xi'an Social Science Foundation 2018 annual subject, C-E Translation on Red Culture Tourism in Xi'an Based on Ecological Paradigm (18L13) appreciate the beauty of China from the green mountains and rivers, but also gives them an insight into the strength of China from the historical promenade. On the day when red culture, along with our national fortitude and perseverance, is brought back to their homeland, it will be a driving force to enhance the soft power in our country.

\section{MAJOR INFLUENCING FACTORS}

\section{A. Social Ideology}

Translation is a kind of intercultural communication activity with a strong purpose [1]. It is not an information exchange at the linguistic level; fundamentally speaking, it is to import the ideology of the exotic culture to the local cultural ideology [2].

As a special field of translation, C-E translation of red culture has strong political overtones. Once it comes to ideology and politics, no media can truly transcend ideology and do cultural communication. In the impact of economic globalization, Chinese ideology also collides with the "advantaged culture" of the west and manifests itself in the field of translation as follows: on the one hand, in the confrontation of the two cultures, western culture takes advantage of the dominant position, to squeeze the underprivileged culture; imperceptibly, it also sets the rules for the translation, to satisfy westerner's needs. In other words, if you want to be accepted and respected by westerners, just follow it; on the contrary, you will be estranged and excluded. On the other hand, western nations also use "internationalization" to seduce alien cultures and differentiate alien cultures. They hope that divisions within disadvantaged cultures inside can weaken the cohesion and integration of dissident discourse systems and then rebuilt value reference system of the dissident culture, so the disadvantaged cultures will give up their own rights discourse, eventually becomes translation tools without thought and soul.

Based on the characteristics of its international communications and external output, the C-E translation of red culture inevitably reflects the social ideology of the source language. Compared with ordinary literary translation, the social function of C-E translation shows itself in directly serving politics. As a result, the translator can not only consider 
the linguistic factors; many other things especially social ideology could not be avoided.

\section{B. Value Idea}

The values is a reflection of existing social objective things. Our values are influenced by so many factors, such as natural environment, social environment, historical environment, political status, economic status, social organizations or political organizations, material or spiritual living environment, family environment, education level, cultural literacy, and so on [3] .

Social values are not immutable. They will change constantly with changes in social and historical patterns. However, they will keep relatively stable and unchangeable in the short term. With the impact of diversified values brought about by social development, the security red culture has was historically and practically pushed to the sovereign countries. The current socialist core value system advocated by our nation is the essential values of our society and national culture. Therefore, building a socialist core value system is of great strategic significance for safeguarding the red culture.

There exist similarities between the core values of socialism and C-E translation of the red culture, because both of them want to get a pursuit of life-giving spring breeze, the spread of silent lubricant effect. The values has a guiding effect on the C-E translation. The purpose of C-E translation is to convey practical information and political intention. If we want to realize the expected effect of C-E translation, we must take the values of target audience into consideration. In the process of translation, language should be flattened, vivid, diversified, popularized to spread our traditional culture and age culture; naturally, a strong cohesion, powerful attraction and forceful incentives will follow, which is the best patriotic education materials.

\section{Audience Psychology}

In the spread of red culture, it should be positioned to embody our unique cultural characteristics of Xi'an as well as historical connotation and future development. This requires that C-E translation, whether to deliver the information or to define our position, should meet the needs of the target audience; only in this way, can we promote national image and achieve the maximum effect of communication. Communication effects is always our first choice [4].

Physiological needs is the basic requirement of target audience, who wants to understand the main content of source language culture. To be frank, the C-E translation of red culture is a blank point for most target audiences. Without understanding the history of red culture, they can not understand the concept the "Belt and Road", so we provide the text that is familiar to target audiences, to make our instruction and expression clear; then through some translation strategies, such as adding, deleting, rebuilding, rewriting etc. to make them feel our cordiality and authenticity. The western media have long advocated the so-called "China Threat Theory", so the audience has a rejection attitude toward China's subconscious development and progress. To some degree, they like the report which can reflect the content of Chinese backward and ignorance. Our C-E translation should be in an unavoidable, literal way to give an effective and timely response, giving no opportunity to some foreign media who has the purpose to distort the truth. Also, C-E Translation is not a process to exchange the written code, consequently, it requires us to have a deep understanding of the cultural background of the double languages, and to fully respect their religious beliefs, value concept, then to have equally communication. The translation should be complied with the aesthetic qualities of the target regions and ethnic groups, especially audience's psychological and emotional experience, to create cultural resonance as well as to satisfy the interest and desire of the audience. If the translators can use the way that the target audience have to express their ideas, which will bring them joy and arouse the affective senses.

\section{Cultural Backgrounds}

Eastern and western communicative differences rooted in their different cultural backgrounds. Chinese traditional culture comes from typical Confucian thought. It is a human-centered culture, which focuses on "ritual governance" and "virtue governance", to pursue the "Unity of Man and Nature", then through the construction of identity and moral education, to shape the Chinese mellow and humanistic character and moral standards. Western culture is based on the material-oriented culture, which focuses on "democratic freedom" and "rules by law", emphasizing "rational speculation" "the opposition between heaven and earth" and "survival of the fittest". When it comes to the communicative way, westerners believe that the inferior culture should accept the survival principle of "natural selection and survival of the fittest" and be eliminated by superior culture if some day. However, it is popular among Chinese that there exists mutual respect and understanding between human beings, nations and cultures; there also exists enough space and room for each culture to survive and develop itself regardless its size and strength. In terms of communicative method, the westerners emphasize on science, rationality, and speculation, and during the process of communication, facts, details and data is always the first concern; Chinese prefer sensibility to ration, caring more on the macro and the overall grasp, advocating the perfect form but subtle expression, so always look solemn and serious.

Due to its interoperability, culture is an integral part of the history of civilization in the world, and there must exist some similarities between each culture; but at the same time, culture is different, because different backgrounds of life, historical heritage, religious beliefs will create a different culture. If a culture does not fit into the pattern of cultural globalization, it will eventually be misunderstood, isolated and marginalized. If it is expected to be accepted by the target language readers, it is necessary to find the meeting point of the two cultures in translation. If the cultural concept concerns what the target language reader has never experienced or even can not imagine the translator must do some transposition when communicating, and provide its audience with relevant cultural background explanations through the corresponding translation strategies. Only when the target readers understand our "cultural output" can we completely realize the exchange of affect and cognition between the two cultures. 


\section{StRATEGIES ON C-E TRANSLATION OF XI'AN RED TOURISM}

\section{A. Adaptation Strategy}

As the object of C-E translation, target readers whose social and cultural background and psychological needs are quite different from ours. So we can understand clearly that the translated version must be "different from one nation to another" and "different from one another even in the same nation". The compilation process is actually a secondary process; under the premise of grasping the original spirit and connotation, what the translator can do is not only to cut down the insignificant things or add some necessary background information, but also to adjust and reorganize the original texts to fulfill the final needs [5].

For example: There exists a sign in the 8th Route Army Office Museum, and it says "Developing Progressive Strength, Fighting for Intermediate Forces, Isolating Stubborn Forces," to our interest, all these words did not appear in its English text. We think it is not a mistake, on the contrary, such texts are completely incomprehensible to readers of the target language, so if possible, a lot of background explanations should be added; differences in value concepts and shared knowledge, there still exists large room to be questioned. Here "Adaptation Translation" used at this time will never reduce the meaning, however, it achieves dynamic equivalence.

\section{B. Overall Strategy}

In the 1960s, French interpreter Danica Celeskiewicz first proposed her theory based on years of practical experience in interpretation. The core idea of interpretation theory is the three translation stages it advocates: the understanding phase, the separation from the source language and the expression stage. Because each nation has its own different historical situation and cultural background, there will be a large number of terminology with its own characteristics. To illustrate these terminology or characteristic words, the interpretive strategy may be adopted. At this point, the object of translation is no longer to focus on the source language, but the information passed in the form of language. The discriminatory evaluation criteria is mainly divided into four levels: the level of language organization, language flu, intonation and other secondary information organization, timely feedback on the communicative effect [6].

Generally speaking, we must first get clear the original text, and C-E translation should not only show its literal meaning, but also the information hidden behind the original cultural background and political history. The so-called political history refers to the historical background of a policy; the overall grasp require we should take the original text and text behind the ideological feelings, cultural images, social background, the baseline mood and so on together into consideration.

For example: There exists an introduction at Malan Museum in XunYi. "During the Anti-Japanese War, based on strengthening a stable Anti-Japanese home front, Guanzhong Subarea gained great achievements in the construction of the Party, the rigime and the economy for the victory of the AntiJapanese War." The Chinese text is concise and logical while the English text is lack of cohesion and coherence, which results in the misunderstanding of relationship between cause and effect. From the overall strategy, we should make some adjustment: During the Anti-Japanese War, based on strengthening a stable Anti-Japanese home front, Guanzhong Subarea made a great contribution to the victory of the AntiJapanese War by the achievements in the construction of the Party, the rigime and the economy. In this way, the effect is put first, then the cause follows because westerns care more about the result, then the details which lead to that.

\section{Cultural Connection Strategy}

Language is the reflection of culture. Translation is not a text conversion but a bridge to communicate between two cultures. Because cultures are rooted in different historical backgrounds and customs, they manifest themselves in their own way. And such differences often lead people to think differently about the same thing, so we must find the intersection and similarities of the two cultures. Cultural connection means a translator should demonstrate original meaning of source language in target language context [7].

The introduction on the history of the Red Army Malan Museum says "On the red earth, the Chinese Communists held high revolutionary banner to carry out..." As all Chinese know the "red land" here is a kind of rhetoric and is a metaphor for the "revolutionary holy land"; unfortunately, the westerns regard "red earth" as simply a division of different soil textures, so it is indistinguishable from the meaning of the source language. Therefore, you should choose to use punctuation marks, make them proper nouns, and attach explanations; otherwise, you can also use implied meanings though selected equivalent vocabulary.

\section{Unification Strategy}

C-E translation is supposed to convey information and promote exchanges so that foreigners can better understand China was, is and will. The unification of translation, especially the unification of proper nouns in Chinese, is the key factor in this work. Without the unification of translations, the effect of news report on China for foreign audience will naturally be decreased. Nonstandard and inconsistent names not only puzzles the reader, but also make them misunderstand place names, national administrative institutions, company names and so on. In Nida's "dynamic equivalence" theory, vocabulary equivalence is one of important part [8]. For professional political vocabularies such as names of people or organizations, there is always a fixed translation method, which cannot be too arbitrary. The pragmatic traits of proper nouns require the use of special words. There may be several references in one place and one unit, but the official name should be only one. The translation of place names is not unified. China issued the "Chinese Pinyin Program" in 1958, which is accepted by the United Nations since 1979. Chinese Pinyin Scheme is regarded as a standard for Chinese names and place names in various Latin alphabets. Then in August 1981, the International Organization for Standardization passed a resolution that the Chinese Pinyin Scheme is an international standard for spelling the names and words of China in the literature work; in addition, we can also follow the translations 
that have been used for many years if without prejudice to the national interests and feeling etc, just to avoid new confusion in the translation of organization names. However, the fact is that the existing translated names of many proper nouns are confusing and lack of unity. A fixed expression with Chinese characteristics is often used at Malan Museum; just in this museum a variety of translated versions are offered for this term, such as "armed worker-peasant armed separatist" "the armed separatists of workers and peasants" "an armed independent regime of workers and peasants" and so on. This term is a scientific concept put forward by Mao Zedong on the theory of the new road of the Chinese revolution. Such a fixed expression with clear Chinese characteristics is translated freely as well as non-unified; and the definite articles and indefinite articles are used without any purpose. Also, some warning signs be seen from in the hall of Malan Museum. Although Chinese often use euphemisms or implicit words to express etiquette or elegance, when translated they should still follow with the westerners' rule. Examples as "Thank you for not smoking" or "Refuse to take pictures" are not consistent with English idiomatic expressions.

\section{E. Rearrangement strategy}

Skopostheorie points out that translation is not a process of code-switching, that is, the process of decoding primitives, but a specific mode of human behavior. It has a certain purpose, and this purpose is already supposed before translation. The translation process does not depend on the effect of the original text as well as the original text on the source language reader, or the function of the original author's original text, but the needs of the sponsor or the patron. C-E translation requires translators to make necessary rearrangement in language conversion in order to achieve the purpose of communication that affects foreign audiences. Reliability is always one of the important needs in C-E translation. In order to achieve a balance in pragmatics, translators must inevitably reorganize textual and sentence structures.

Since the 18th National Congress of the Communist Party of China (CPC), China has witnessed profound changes in its national conditions. Grasping the spirit of central concept then dealing with it innovatively is a great task. Based on the rearrangement strategy, the translator should render properly those frequently used terms in Chinese political document into English without sounding repetitious or monotonous. C-E translation text is not only concerned on the literal meaning of every concept, but the hidden meaning behind the text to express the deeper and more comprehensive factors it contains, to reflect the internal logic of the text. Usually the purpose of political document is clear and strong, so the text must be loyal to the central government needs and fulfill the leader's political intentions and direction. The basic requirement of our foreign discourse system is supposed to tell Chinese stories in reasonable way, which will be acceptable to attract more people to understand Chinese Tao, so to improve China's international influence, and let the world hear the voice of China. Rearrange the source language text in form, adjust relationship between each chapters in content, and change the complex into graphic way to make it obvious and concise. So we can rearrange the form of our work report: format the paragraphs not only on its content, but also the needs of target reader; reproduce the complex data and contents by diagram, to make the important lengthy statement read easily; strengthen the rhythm of the speech to attract the audience; break the original digital arrangement, and so on.

For example, this passage comes from Report on the Work of the Government 2016, and it says "Fellow deputies, blueprints for Xi'an's development in the coming 5 years are all set, and the sound of the horn for catching up and surpassing is on the air. Let us unite closely around the Party Central Committee with Comrade Xi Jinping as General Secretary. Under the leadership of the municipal Party Committee and with more strict and steady thoughts and disciplines, we will further push forward the construction of quality Xi'an and strive to build a well-off society in all aspects and construct Xi'an into an international metropolis with cultural and historical characteristics." Actually, "the sound of the horn for catching up and surpassing is on the air", which is the text with obvious characteristics of internal communication; in addition, the "Party Central Committee with Comrade Xi Jinping as the General Secretary" should be translated as "Party Central Committee headed by General Secretary Xi Jinping". Especially the word "comrade", the authority can only use it within the Party and the armed forces; there is nothing wrong with it, but translator does not need to translate it completely.

\section{CONCLUSION}

The process of red culture's external diffusion is actually a process of sharing our national history with the outside world. It meets not only the requirement of the times but also the contemporary challenge. It has improved the development and utilization of red tourism resources in Xi'an and inherited its classic red culture. The "Belt and Road" initiative strategic plan will effectively increase the development and utilization of tourism resources, and it will be able to fully mobilize the geographical advantages of Xi'an and promote the diversified use of historic resources.

\section{REFERENCES}

[1] Bielsa Esperanca \& Bassnett,Susan. Translation in Global News [M]. Shanghai: Shanghai Foreign Language Education Press,2010.

[2] Eugene J. H. The Language of Tourism in English[M]. New York: Regents Publishing Company,Inc.1976.

[3] Newmark, P. Approaches to Translation [M]. New York: Prentice Hall International (UK) Ltd., 1988.

[4] Nord, C. Translating as a Purposeful Activity: Functionalist Approaches Explained [M]. Shanghai: Shanghai Foreign Language Education Press, 2001.

[5] Vermeer, Hans J. "Skopos and Commission in Translational Action". The Translation Studies Reader. Ed. Lawrence Venuti. London and New York: Routledge,2000.

[6] Lefevere, Andre. Translation/ History/Culture A Sourcebook[C]. Shanghai: Shanghai Foreign Language Education Press,2010.

[7] Wilss, Wolfram. The Science of Translation Problems and Methods[M]. Shanghai: Shanghai Foreign Language Education Press,2001.

[8] Nida,Euguene. A. Language,Culture,and Translating [M]. Shanghai: Shanghai Foreign Language Education Press,1993. 